\title{
Transatlantica
}

Revue d'études américaines. American Studies Journal

\section{Discourse of Slavery: Freedom and the Negotiation of Power and Identity in Context}

\section{Lori Lee}

\section{(2) OpenEdition}

10 Journals

\section{Édition électronique}

URL : https://journals.openedition.org/transatlantica/6237

DOI : $10.4000 /$ transatlantica.6237

ISSN : $1765-2766$

Éditeur

Association française d'Etudes Américaines (AFEA)

\section{Référence électronique}

Lori Lee, « Discourse of Slavery: Freedom and the Negotiation of Power and Identity in Context », Transatlantica [En ligne], 2 | 2012, mis en ligne le 21 mai 2013, consulté le 06 avril 2023. URL : http:// journals.openedition.org/transatlantica/6237 ; DOI : https://doi.org/10.4000/transatlantica.6237

Ce document a été généré automatiquement le 6 avril 2023.

\section{(c) (i) (9)}

Creative Commons - Attribution - Pas d'Utilisation Commerciale - Pas de Modification 4.0 International - CC BY-NC-ND 4.0

https://creativecommons.org/licenses/by-nc-nd/4.0/ 


\title{
Discourse of Slavery: Freedom and the Negotiation of Power and Identity in Context
}

\author{
Lori Lee
}

1 Consider the following quote from a former slave: "The Master says we are all free, but it don't mean we is white. And it don't mean we is equal (George King, 1930, quoted in Baker and Baker, 1996, 238)." This insightful observation eloquently captures the essence of this essay. What people say is not always what they mean, and what they mean is mediated through both their context and the identity of those engaged in conversation. The institution of slavery in the Americas constructed a legacy of racism and inequality, which was exacerbated in the process of emancipation and reconstruction. Elements of this legacy find expression within Works Progress Administration interviews with former slaves. These narratives, both through what they say and do not say, reveal that constructions of racial inequality did not disappear with the end of the institution of slavery. The contextual creation of slave narratives and the processes of their construction and reconstruction resulted in a negotiation of power over the authentic discourse of slavery. These media also provide insight into how the negotiation of identity was influenced by constructs of race and ethnicity. This essay examines these negotiations and particularly emphasizes the ways in which the contexts of emancipation and the circumscribed condition of the freed individual mediated the meaning of freedom in the lives of the formerly enslaved. The impact of racial inequality on the negotiated identities of African Americans and Anglo Americans are also explored.

2 The term discourse has two connotations, one linguistic and one social. The linguistics form of discourse refers to "connected segments of speech or writing" (Conley and O'Barr, 1998, 7). Analysis of linguistic discourse requires examination of how such segments, or texts, are structured and how they are used in communication (ibid.). Discourse in its more abstract, social sense has been discussed in the work of Foucault (1993). Foucault defines discourse as communication that takes place within a society 
about an issue or set of issues (Conley and O'Barr, 1998, 6). It examines how something gets talked about. This is intimately related to how people think about that issue and how they act in relation to it. The dominance of a particular discourse within a society inevitably reflects the power structure of society (ibid.). Through talk, the dominant discourse can be sanctioned, questioned, or subverted. Following Conley and O'Barr, I refer to the linguistic form of discourse as microdiscourse and the social form as macrodiscourse (ibid.). These dual aspects of discourse are examined through the form of narrative. Following a discussion of the challenges of working with slave narratives, audiotaped slave narratives are analyzed to assess microdiscourse. Then select written narratives from Mississippi are analyzed to examine the macrodiscourse of slavery in a regional context.

\section{Challenges of working with slave narratives}

3 The Works Progress Administration began a Slave Narrative project in 1937 to obtain information about the experiences of slavery from former slaves. Writers had transferred nearly twenty-three hundred slave narratives to the Writer's Unit at the Library of Congress by the end of the project (Baker and Baker, 1996, 7). The selective collection of these narratives that will be analyzed for this essay spans from 1937 to 1951. These narratives are analyzed to gain insight into the macrodiscourse and microdiscourse of slavery-how former slaves talked about slavery to interviewers from government organizations and the broader discourse that was encompassed by and within these narratives.

4 There are several challenges in using the slave narratives as a source. One issue is the long interval of time that elapsed between emancipation and the interviews. The interviews were conducted from 1937-1951, over seventy years after emancipation. Consequently, many informants were children during the era of slavery. One's experience within slavery was variable in many ways for children and adults. Therefore a number of the narratives offer a child's perspective of slavery. The seventy-plus year lapse also interferes with memory.

5 Another difficulty is interviewer bias. Most interviewers were white (except in Virginia) and most informants were elderly blacks, creating clear class and racial boundaries between the interviewer and the interviewee. The respect traditionally accorded to the elderly in Southern society did offer some leeway to the former slaves in telling their stories and allowed them an opportunity to speak openly (Berlin et al., 1998, xx). Racial and gender etiquette of the 1930s and 1940s impacted interviews as well. For example, an African American male may have been reluctant to reveal some aspects of his past to a young, Caucasian female (Baker and Baker, 1996, 4). Just as informants' narratives evoke what they felt was significant about slavery, the interviewers' questions that invoked these narratives reveal what they felt was most significant. This situation was rendered more complex by the fact that many of the interviewers and informants lived in the same towns. White interviewers were often related to the "local elite," a relationship that was usually known to the men and women being interviewed (Rawick, 1977a, xlii). Therefore, informants would likely have tailored their narratives to accommodate this potential dilemma. Vague answers were probably as much a consequence of suspicion of the interviewers and their motives as they were of fading memory. 
Significantly, many narratives were edited at least once prior to publication. When the interviews were published, the questions were removed and the narrative was pieced together to represent a more or less steadily flowing narrative. Editing was done at the writer and/or appraiser's discretion. This meant that if a writer and/or appraiser perceived some material to be offensive or "untrue" then it was sometimes removed from the narrative or the narrative itself was not sent on to Washington D.C. Insight into this process can be found in the appraisal sheets for individual narratives in the Alabama collection, which became a part of the historical record. C.H. Wetmore noted that narrations which presented slavery as humane were "believable" and "convincing," whereas those that depicted conflict between slaves and slaveowners or overseers were "suspect" (paraphrased from Rawick, 1977a, xxxx). Wetmore's comments did not prevent the narratives he documented from being sent to Washington D.C. unedited. However, they do exemplify the kinds of things that were suggested for editing or removal and these suggestions were probably implemented in other cases.

7 What was deemed offensive, inauthentic, or "untrue" in the narratives was mediated by context. During the Civil War, abolitionists depicted slavery as an evil that must be cast out of the United States. But during the late nineteenth and early twentieth centuries, white northerners and southerners began to redefine slavery as a benign and even philanthropic institution, recalling themes used by planters in defense of slavery. The rancor and severity of the post-war period was contrasted with the supposed harmony of the era of slavery (Berlin et al., 1998, xiv). This redefinition of slavery was one byproduct of the post-Civil War national reconciliation process.

8 Therefore the geographic context and the social context, in the form of racial tensions and hegemonic relations, impacted the censoring of the narratives. By defining aspects of the narratives as inauthentic and selectively publishing perspectives of slavery that resonated with the contemporary white perspective of the slavery experience, some W.P.A. writers and appraisers were circumscribing the voices of the former slaves and filtering their words through an imposed lens. By editing the interviews, writers were asserting power and reconstructing the narrative. Editing represents a manner of silencing, which is a form of linguistic oppression (Ochs and Capps, 1996, 35). Through narrative, individuals define themselves. When others modify autobiographical narratives, they are redefining and contesting self-definition. "This type of activity was very often the work of strong-willed individuals, deeply interested in the project, who 'knew' how the 'true' history of slavery should read" (Berlin et al., 1998, xxxii).

9 John Faulk, who recorded the spoken versions of the narratives, was certainly sympathetic to the informants he interviewed and was, in his own words, "deeply interested in the project." However, even the perceptions of well-intentioned people were mediated by their place in society and history. In an interview forty years after the Slave Narrative project, Faulk narrated an incident that took place during the project that made him aware of his own prejudices:

I remember sitting out on a wagon tongue with this old black man-completely illiterate-down near Navasota a plantation there and I was telling him what a different kind of white man I was. I was really getting educated on blacks and their problems, except we called 'em colored folks. I said, "You know, you might not realize it but I'm not like the colored-the white folks you run into down here. I believe in giving you the right to go to school, to good schools. Now, I know you don't want to go with white people-I don't believe in going overboard on this thing 
-but I believe colored people ought to be given good schools. And I believe you ought to be given the right to vote." And, I remember him looking at me, very sadly and kind of sweetly, and condescendingly and saying, "You know, you still got the disease honey. I know you think you're cured, but you're not cured. You talking now you sitting there talking and I know it's nice and I know you a good man. Talking about giving me this, and giving me that right. You talking about giving me something that I was born with just like you was born with it. You can't give me the right to be a human being. I was born with that right. Now you can keep me from having that if you've got all the policemen and all the jobs on your side, you can deprive me of it, but you can't give it to me, cause I was born with it just like you was." (quoted in Berlin et al., 1998, 330)

This narrative illustrates the way that the attitude of an interviewer was shaped by the contemporary metadiscourse concerning the differences between ethnic groups. It also provides a powerful implicit example of differing definitions of freedom, who had the authority to restrict freedom, and what freedom meant in the everyday lives of African Americans.

The imposition of a standardized African-American dialect also lends further distortion to the narratives. Some interviewers were concerned with rendering correct dialect. A number of other interviewers used what were purported to be regional black dialects when they were encoding the narratives. Jones noted that Allen "uses excellent English," however he rendered the written version of his narrative in dialect (Rawick, 1977a, xxxiii). The particular dialect imposed was often a version created by John Lomax (Director of the Federal Writer's Project) that was designed to reduce the use of stereotyped dialects (ibid.). By failing to include the orthography of each interview, much meaning is lost and the text becomes homogenized. Ironically, this homogenization leads to maintenance of stereotypes.

The audiotaped interviews provide evidence that the Southern dialect of the interviewers was at times much heavier than that of the informants. However, their dialect is never captured in the written documents that include their comments. Dialect was an index of identity in the 1930s southern United States. Speech was believed to demarcate distinctions between differing social groups, this ideal is indicated by the imposition of dialect where none existed and the absence of it where it was present. The reality of the situation was far more complex than written documents alone can reveal. Dialect was believed to index a variable identity, and it did, but the facet of identity it indexed in the narratives was often imposed.

As a composite, the W.P.A. narratives present many challenges. By editing and censoring the narratives, writers, editors, and directors modified the self-expression of the informants. Self-expression is a tool of self-definition. By modifying the selfdefinitions of informants, a new identity is carved. This identity reflects its negotiated status in that it is neither a true representation of either the self-identity of former slaves nor the imposed identity of W.P.A. workers and broader society. It is something in between. According to Lawrence, all the narratives that reached Washington D.C. were edited to some degree (Rawick, 1977a, xciv). Like all primary sources, they contain a number of weaknesses as historical evidence. However, particularly taken as a group, they do provide insight into many aspects of the African American past from slavery, through Reconstruction, and into the Great Depression. Certainly their use creates challenges, but when utilized cautiously the voices of former slaves that have been 
constrained, by social and geographical context and censoring, form a chorus and this chorus carries a palimpsest of notes that form a composite identity.

\section{Audiotaped Narratives}

Written narratives lose layers of meaning in the absence of their spoken counterparts. One former slave, in recounting a spiritual to a researcher, remarked: "it can't be sung without a full heart and a troubled spirit" (Allen et al, 1867, xxiii). Similarly, narratives lose much of the emotional aspect that saturates them with meaning when they are reduced to written form. It is an entirely different experience to listen to the narrative told by the individual who experienced it. An era often conceptualized as the distant past is thrust into the present as the voices bring to life the experiences of those who tell their personal stories.

Bakhtin wrote:

The living utterance, having taken meaning and shape at a particular historic moment in a socially specific environment, cannot fail to brush up against thousands of living dialogic threads, woven by socio-ideological consciousness around the given object of utterance; it cannot fail to become an active participant in social dialogue (Bakhtin, 1981, 276).

The object, or subject, in this instance is slavery. Before any utterance on the part of the narrators, the word "slavery" is already laden with the characteristics that Bakhtin eloquently describes. The narrative is initiated, gaining "meaning and shape" at a given point in time which provides it with a specific geographical, cultural, social, and ideological context. At this point in time the strands of the narrative becomes an "active participant in social dialogue." Aspects of the "socio-ideological consciousness" through which talk about slavery is constructed and contested become transparent in identity and power negotiation.

The method used to analyze the audio narratives is a combination of discourse analysis and analysis of the structure of the narrative. Bar-On and Gilad developed a method for examining the structure of interviews with Holocaust survivors (1994). Prior to analysis, Bar-On and Gilad were aware that interviewees might be unwilling to talk about certain issues or might try to distort them. The interviews were done over fifty years after the Holocaust, creating the problem of fragmentary memories mentioned above. Bar-On and Gilad also noted that it was difficult for interviewees to describe through words their experiences and the emotions that were conflated with them. Further, "The researchers, through their too-strong conceptual framework, may overshadow the fragile language structures that survivors developed to describe those events" (ibid., 86). The parallels with the experiences of interviewees and interviewers of the Slave Narrative Project are self-evident.

In analyzing interviews, the researchers focused on where informants spoke at length and where they were brief; what they narrated and what they argued, described, and reported. They looked for patterns among the endless process of choice, both forward and backward in time and space; choice patterns that reflected a tension between conservation and change; and concentration on the past, the present, or the future time perspectives. Bar-On and Gilad examined how narrative reflects normalization strategies of facing the threatening past and future. "Strategies allow people to smooth out corners in their stories, especially corners they find difficult to confront in the 
present" (86-87). They considered how the underlying strategy served the narrator's goals and whether or not some questions were perceived by the informants as value judgments. I combine this approach with discourse analysis to examine issues of identity and power negotiation between former slaves, their interviewers, and subsequent editors of the narratives.

The audiotapes of the spoken narratives used for this essay were formatted for a public radio program (Berlin et al., 1998). In this program, the former slaves seem to offer autobiographical accounts, but they are transformed, by editing and censoring, into biographical representations because the audio narratives were edited for the radio program. A complete copy of the transcribed Fountain Hughes interview was obtained and comparison revealed that the radio version was edited and rearranged. Continuing into the end of the late twentieth century, the slave narratives are still being used to fit a purpose beyond simply relating the everyday experiences of life under slavery. ${ }^{1}$

\section{Fountain Hughes}

20 When prompted by his interviewer, Hermond Norwood, to "talk away there, you don't mind do you, Uncle Fountain?" Fountain Hughes ${ }^{2}$ replied "No." and then launched into a speech about how people should stay out of debt and never buy things on credit. In this initial interaction, much information can be extracted about identity negotiation. Norwood prompts Hughes to 'talk' and consequently he began to talk about what concerned him in the contemporary present-debt. Hughes offered his advice to the younger generations and intertextualized that advice with a narrative of his own experiences in avoiding debt and remaining happy. In offering advice, Hughes reified his status as an elder, which entails offering advice to the young. In the narration he tacked back and forth between past and present, connecting them.

21 Norwood, the interviewer, addressed Hughes as "uncle." By using the term "uncle" to address Hughes, Norwood used a common contemporary practice exercised among African Americans (Allen et al., 1867, xxix). This practice dates to the era of paternalistic slavery when the enslaved youth were referred to as "girls" and "boys" by the planter family, and through aging became "aunts" and "uncles" (Berlin et al., 1998, $\mathrm{xxxv}$ ). Whether or not it was insulting to the former slaves to be addressed by whites using this diminutive term in the 1930s is unclear. Slaves often referred to the interviewers as "Miss," "ma'am" and "sir," thereby exhibiting expected racial etiquette of the 1930s and 1940s (ibid., 13,18-19). This racial etiquette is a survival of the racial inequality promoted by American racial slavery. Hughes spoke slowly, narrating in an even tone for most of the duration of the interview. This had a "naturalizing" effect; he reported the experiences rather than reliving them and imparting them with emotion.

Hughes's choice to emphasize debt and its consequences is significant. Debt and indebtedness are concepts that were used by Anglo-Americans on the eve of emancipation and during the era of Reconstruction to position the new status of freed blacks within the society and to foster a sense of obligation. This sense of obligation is captured in the following quote taken from Advice to Freedmen (1864), one of a number of texts published as a means of indoctrinating freedmen into society: "With treasure and precious blood your freedom was purchased. Let these sufferings and sacrifices never be forgotten when you remember that you are not now a slave but a freedman" 
(quoted in Hartman, 1997, 130). Freedom presumably indebted the newly freed to the nation. This obligation functioned to maintain the subjugated status.

The very bestowal of freedom established the indebtedness of the freed through a calculus of blame and responsibility that mandated that the formerly enslaved both repay this investment of faith and prove their worthiness. The temporal attributes of indebtedness bind one to the past, since what is owed draws the past into the present, and suspend the subject between what has been and what is [...]. Moreover, indebtedness was central to the creation of a memory of the past in which white benefactors, courageous soldiers, and virtuous mothers sacrificed themselves for the enslaved (Hartman, 1997, 131).

By remaining debt-free, Hughes was able to maintain a distance from his past experiences under slavery. In the creation of a memory of the emancipation process that privileged the contribution of whites over the contribution and experiences of blacks, Anglo-Americans were able to structurally reverse the obligation they should have had to those from whom they extracted labor and life without payment or consequence. This indebtedness was a means of maintaining the subjugated position of the formerly enslaved within society. The language in Advice to Freedmen promotes this maintenance:

With the enjoyment of a freedman's privileges, comes also a freedman's duties and responsibilities. These are weighty. You cannot get rid of them; they must be met; and unless you are prepared to meet them with a proper spirit, and patiently and cheerfully to fulfill these obligations, you are not worthy of being a freedman. You may tremble in view of these duties and responsibilities; but you need not fear. Put your trust in God, and bend your back joyfully and hopefully to the burden (quoted in Hartman, 1997, 125).

This statement foreshadows the "indebted servitude" that replaced slavery for a number of freedmen.

Next in the interview with Hughes, Norwood asked: "Do you, how far back do you remember?" Hughes replied: "I remember." A few sentences later, he states: "Now in my boy days, why, uh, boys lived quite different from the way they live now..." Again he is connecting past and present. He chose the term "boy days" instead of "slavery days" which is used by some narrators. This emphasizes his primary self-identification as a boy rather than a slave. This led him into a discussion about clothing, past and present: "An' I been, oh, oh you wore a dress like a woman till I was, I believe ten, twelve, thirteen years old." Here he switched from past tense to present and from "I" to "you." As Kerby notes, "the past is not always experienced as fixed, over and done with" $(1991,28)$. Hughes continual switching between the two blurs them and indicates that for him the past is not a remote entity. By using "you," Hughes was creating some distance between himself and the "dressing like a woman" comment. The interviewer bridges the distance that this gap created by asking: "So you wore a dress?" To which Hughes replied: “Yes. I didn't wear no pants, and of course didn't make boys pants. Boys wore dresses. Now only womens wearing the dresses and the boys is going with the, with the womens wearing the pants now and the boys wearing the dresses. Still, [laughs]" (Norwood, 3).

26 To illustrate the type of editing done to the audiotaped version of the narratives, following is an example of the presentation of the above excerpt as it is spliced together in the audio version: “Yes. I didn't wear no pants, and of course didn't make boys' pants. Boys wore dresses. The womens wearing the pants now and the boys wearing the dresses. Still, [laughs]" (Berlin et al., 1998, 282). Given the audio nature of 
these narratives, the editing is undetectable to the listener without a written version of the narrative. The narratives are included in full in the accompanying book that comes with the audiotaped narratives (Berlin et al., 1998). Despite this, the editing of the audio versions is unfortunate and misleading. Though the intent is perhaps to present excerpts that are more lucid, the effect of the editing is the same as when it is performed with the written narratives, it circumscribes the microdiscourse. The representation of the informant is shaped and molded.

Norwood led Hughes into a discussion of slavery: "Who did you work for Uncle Fountain when-?" Hughes replied: "Who'd I work for?," indicating that he wanted clarification. The interviewer did not supply it, he replied: "Yeah." Then Hughes had to rephrase his question: "When I, you mean when I was slave?" (Norwood, 3) This changed the direction of the conversation. Hughes began to narrate his life during slavery. His use of "was" indicates the distancing of this experience. As he transitioned into this part of the narrative, Hughes used a number of linguistic fillers, "Well, I belonged to, uh Burney, when I was a slave. My mother belonged to Burney. But my, uh, but, uh, we, uh, was all slave children" (ibid.). The use of fillers is uncommon in the rest of Hughes narration. Therefore its presence is significant here. Talking about this experience must have been difficult and trying to express it and mentally return to that situation to narrate it created these spaces in the narrative. This process is also indicated by pauses when Hughes looked for words to express his meaning. For example, he stated: "an' they all had uh, what you all, (pause), I might call it now, uh, jail sentence, was jus' the same as we was in jail" (ibid.). He emphasized 'jail sentence.' Searching for a way to give meaning to his own experience and provide an example that would translate to his listener was important to Hughes and he often used metaphors and similes to convey his meaning.

"It was what they call, we were slaves. We belonged to people. They'd sell us like they sell horses an' cows an' hogs an' all like that... jus' same as you bidding on cattle you know" (ibid.).

This excerpt implies Hughes's definition of freedom. Being a slave is 'belonging' to someone, freedom is its opposite. This oppositional definition of slave/free person was encoded in the Constitution of the United States. Consider Article 1, Section 2, one of two provisions in the Constitution that refers to slaves:

Representatives and direct taxes shall be apportioned among the several States which may be included within this Union according to their respective numbers, which shall be determined by adding to the whole number of free persons, including those bound to service for a term of years, and excluding Indians not taxed, three-fifths of all other persons (quoted in Owen, 1864, 141-42).

“" 'Other persons' [slaves] are called, in contradistinction to "free persons"-therefore persons not free" (Owen, 1864, 142). The authors of the Constitution were careful to avoid the use of the term 'slave.' And thus slaves became 'other' persons, an apropos term given their subaltern status. These 'other persons' comprised a large percentage of the population of the United States and the explicit failure to articulate their existence in more definitive terms is revealing.

Though Hughes's narration remained fairly even-pitched throughout, he said "we were slaves" loudly for emphasis. His comparison of the experience of being sold to animals at auction is common in a number of other narratives. He employed it again, later: “Now, uh, after we got freed an' they turned us out like cattle, we could, we didn' have 
nowhere to go... So, we had, uh, we had what you call, worse than dogs has got it now. Dogs has got it now better than we had it when we come along" (4). This narrative strategy emphasized the inhumanity of the experience. It was also a strategy for "smoothing out corners" in the story surrounding issues that were "difficult to confront in the present." It connects the past with the present and provides an accessible connection to the experience for the interviewer as well.

Using analogy and metaphor provides a means of distancing, which creates a comfortable space in the interview for discussing difficult issues. Hughes's description of his experiences is primarily rather 'matter-of-fact,' divorced from emotion. This detachment is another distancing strategy, a normalization strategy for dealing with the threatening past, and is found among Holocaust survivors as well (Bar-On and Gilad, 1994). Hughes expressed his discomfort with discussing slavery and Reconstruction: “You wasn't treated as good as they treat dogs now. But still I don't like to talk about it. Because it makes, makes people feel bad you know. I could say a whole lot I don' like to say. An' I won't say a whole lot more" (Berlin et al., 1998, 5). A number of other former slaves expressed similar sentiments. By maintaining silence, they were able to deny aspects of their former identities that they found disturbing or that they thought would be disturbing to others. Slavery was not an acceptable topic within the macrodiscourse of the South in the 1930s. This silence, and what the narratives do not say, speaks volumes. The burden of his trials during slavery is captured in Hughes's reflection on that experience from the contemporary present: "I don't know how I am living" (ibid., 7).

\section{Laura Smalley}

33 Smalley $^{3}$ used a similar "matter-of-fact" strategy to relate her experiences during slavery. She used much more repetition than Hughes, however. She wanted to be sure the interviewer was involved in the narration. This desire was apparent through her continual interjection of "you know": "Jus' like, you know, you bring a whole lot of children you know, an' put them down, you know, at one house..." (Berlin et al, 1998, 287).

Like Hughes, Smalley used animal metaphors as a narrative strategy,

An' they had certain time to come to them childrens. I think about, just like a cow out there will go to the calf, you know. An' you know they'd have certain time, you know, cow come to his calf in, at, at night. Well they come at ten o'clock everyday, ten o'clock to all them babies (ibid.).

Smalley talked at length about a "whipping" that she witnessed. It was a brutal beating. The lengthiness and detail of her response indicates that this was something very memorable and that it was important for her to express. A number of the narratives discuss "whippings." These make an appearance despite the censoring (by both self and interviewer) of mistreatment and brutality. Rawick surmised that this was a result of the commonality of whippings: "If the ex-slaves had one thing in common, it was their universal consciousness and hatred of whipping." Whipping was a form of mistreatment and not all former slaves were comfortable discussing this violence openly. Some were able to circumvent the problem of telling of their own harsh treatment by transferring it to descriptions of whippings and brutality on a neighboring plantation. This strategy creates social distance between one's self and the 
experience that one wants to discuss. This social distancing reveals the complexity of contemporary race relations. narratives that recalled violence. Former slave Henrietta King suffered a beating that disfigured her face for life. During the beating, her head was held in place by the bottom of a rocking chair, this resulted in the left side of her face being crushed and bones and teeth permanently lost. After narrating this experience, King told the interviewer: “Here, put yo' han' on my face-right here on dis lef' cheek-dat's what slave days was like" (Berlin et al., 1998, 21). With this strategy, she brought the past into the present and incorporated the interviewer into her experience. She expressed that words alone cannot capture slavery in the way that touching a remnant of its brutality and inhumanity can. In stating: "I could tell you 'bout it all day, but even den you couldn't guess at the awfulness of it" (Berlin et al., 1998, 306), Delia Garlic also captured this difficulty of expressing the nature of slavery through words.

\section{Harriet Smith}

39 Harriet Smith ${ }^{4}$ emphasized the clarity of her memory of her past experiences. She was more interactive with the interviewer than Hughes or Smalley. When the interviewer asked questions for clarification, Smith either corrected him or affirmed her original answer and elaborated upon it. This was clearly her story and she wasn't willing to allow the interviewer much room in the negotiation of it.

In her narration of the past, Mrs. Smith emphasized her own abilities and the abilities of other African Americans. "That's right. We could ride horses. We could jump on them horses, saddle sometime, ride them sometime. We learn how to do-I could stan' flat-footed on the groun', jump on a horse sideways [...] All of us, all of we raised to ride 
horses" (Berlin et al., 1998, 316). Smith also emphasized her ability to work hard and efficiently: "Knock out around five hundred pounds of cotton. Then walk around the fiel' an' hun' watermelons, pomegranites an-" (ibid., 6). She said this with a sense of pride.

After emancipation, Harriet Smith married an African American politician and religious leader who was later murdered. His death was an important event in her life and she returned to it several times in her narrative. The horror of it was exacerbated by the fact that she knew the boy who killed him and she had nursed him as a child: "My husban' was uh, he was known by white folks. He was well, uh, when he got kill them white folks was just crazy about him. That boy killed my husban', I nursed him when he was a baby" (Berlin et al., 1998, 325).

Through his line of questioning, it is clear that the interviewer (John Henry Faulk) inferred that Mr. Smith was murdered as a result of his political activities, particularly for rounding up voters during Reconstruction. He also clearly assumed that the murderer was "colored": "Well, he uh, did the colored folks not like [your husband]?" (ibid., 327). Not satisfied with Smith's reply, he rephrased the question: "Well, what I was, what I'm trying to find out is, how come him to kill your husband. Was it over politics?" (ibid.). Smith paused before replying, vaguely, "Uh huh, politics and different things you know, poor white people" (ibid.). Mrs. Smith avoided offering her opinion at this point, and "poor white people" was spoken almost as a whisper. This is followed by a confused exchange between the two about who (not the name, Walter Beyer, which is given early on in the interview sequence) killed Mr. Smith. Faulk assumed the murderer must have been related to the Smiths. Mrs. Smith clarified that he was a poor white man. "The peoples was poor peoples you know. Rich white people don' bother nobody" (ibid.). Faulk responded with surprise: "Oh Walter Beyer was a white man? [...] I didn't know he was a white man." He then resumed his line of questioning about the motive. Mrs. Smith, finally exasperated, said: "Jus' 'cause he didn' like him. Because our boys was well learned...” (Berlin et al., 1998, 328).

This excerpt from her narrative emphasized the macrodiscourse of ethnicity that continued from slavery into Reconstruction. Smith expressed trepidation of poor whites, this was frequent among written slave narratives that mention whites. Poor whites were hired by wealthy whites to enforce punishments, both as overseers and as patrollers. Patrollers would travel around and watch out for enslaved African Americans who were away from their owners without permission. Mrs. Smith may also have made a distinction between poor and rich whites to make her interviewer at ease during the interview and ensure that he realized she was not transferring negative associations to him.

Faulk initially let the question of 'why?' fall aside; he seemed to sum it up to violence toward and among African Americans. But when he found out that Beyer was white, he had to seek a new answer. Mrs. Smith's response indicated that during Reconstruction, some whites were not supportive of education for blacks. However, her answer was still evasive, indicating the political climate of the time and the possible repercussions that her honest disclosure might bring to fruition. Her answer is a partial truth. Through interaction with Faulk, Smith creates a fragmented identity for Beyer. It seems that Faulk's assumptions about the ethnicity of Beyer began with Smith's assertion that she had nursed him as a child. The practice of black women nursing white children was common during slavery, and it continued after emancipation. Smith's narrative 
provides insight into contemporary assumptions about race and ethnicity and their relevance for the past, present, and future. Analysis of the written narratives reveals that race, ethnicity, and status are common themes in the written narratives, and their contextual creations, as well.

\section{Documentary Analysis: W.P.A. Narratives}

Taken as an entire collection, the slave narratives provide myriad reflections of identity and interpretations of the concept of freedom. The most salient aspects of identity found within the written narratives deal with constructs of race and status. Several of the informants label different groups of whites as 'poor white trash.' Ida Henry recalled: "Close to our Master's plantation lived several families of old 'poor white trash' who would steal me Master's hogs and chickens..." (Berlin et al. 1998, 198). Hal Hutson said: "All of us niggers [sic] called all the whites 'poor white trash.' The overseer was nothing but poor white trash..." (Brown and Brown 1996, 206). A number of the informants referred to the overseers as poor white trash. By doing this, the informants were leveling the status of the whites they discussed and creating a status hierarchy, which placed the status of these whites below their own. This highlights the fact that identity is a relationship; each variable of identity is defined in relation to something else. Class and status do not exist without these relationships.

Race, in the form of physical attributes, was often used to define class and status. Several informants made statements about skin color and its associations. Chaney McNair said: "Back in Ft. Scott where I worked there's this little girl, beautiful little girl with long curls. I wondered why God made me black and ugly and that little girl so white" (ibid., 276). Ms. McNair is defining her self-concept in relation to the other girl. Della Fountain stated: "Father finally had to whip Joe to make him know he was black" (ibid., 157). This statement implies that racial status had to be learned. As in this case, this lesson was often taught through violence. Slaveholders reminded the enslaved of their racialized status in other ways as well. Robert Glenn narrated an incident of when his father tried to purchase him from his owner, the owner became enraged and said: "You think you are white do you? Now just to show you are black, I will not let you have your son at any price" (Berlin et al., 1998, 284). This demarcation of race was made continually, in more subtle ways, such as always referring to the enslaved as "darkies" or "niggers" which were terms that whites reserved for people of color. This was such a common practice that in many of the narratives, former slaves refer to themselves using these terms when speaking of the past, although the common term of use in the 1930s was "colored people." 'White,' 'black,' and other color connotative terms are found throughout the narratives; these were an important index of identity and they reflect the social tensions surrounding color as a basis of identity. By reducing complex color differences into black and white, the hybridity and diversity of the reality of skin color was denied. This false dichotomy eased the reification and essentialization of race based on skin color. This color system was used to maintain racial inequality and racism long after the end of the institution of slavery itself.

The continuity of this racialization is found among some of the Mississippi narratives. A number of these narratives include a physical description of the interviewee, written by the interviewer, which sometimes includes an essentialization of character as well. Following are some examples: 
William Edward Black. Ex-Slave, 91 years. "Parson Black," as he is known in Holly Springs, is 4 feet, 10 inches tall, weighs 120 pounds, color dark brown, with an enormous head [...]. Is considered crazy, but is shrewd enough to capitalize on his peculiarities (Rawick, 1977b, 143).

Matilda Clifton [...]. She has a typical Negro characteristic in that she likes for people to give her things, and she doesn't hesitate in asking for the articles that she desires (ibid., 414).

Gabe Emmanuel is the Blackest, black Negro one ever could hope to see. He is a stopped, wabbly old man, 85 years old, weighing about 135 pounds [...]. He lives in the Negro quarters of Port Gibson, and has the courtesy and gentleness of all slavery Negroes (ibid., 681).

Charles Bell [...] at his present age of eighty-one, is hale and erect, in color medium brown (as browns in this sense go) set off by a growth of closely kinked benevolentlooking white wool covering his head, cheeks, chin and most of his neck. He is five feet, six inches, tall and weighs one hundred sixty-five pounds. His upper teeth present a solid gold front which condition, be it noted, is less disfiguring to the negro face than to the white; in fact, the color scheme is rather good, which may account for the pride most negroes take in the possession of gold teeth. considered is how geographic context impacts slave narratives. Ideally, this question would be asked of the slave narrative collection as a whole. For the purposes of this essay, the question will be asked of specific regional data. Life experiences were variable during slavery, and the present regional approach is not meant to homogenize these experiences by region. Therefore patterns that appear within a region will be examined with the explicit acknowledgement that variability does exist. A collection of the Mississippi slave narratives will be used to consider the question of the impact of geographic context.

51 The descriptions of former slaves taken from Mississippi slave narratives set the tone for the discourse of slavery in this state. Paternalism and stereotypes abound. An interesting aspect of the Mississippi narratives is that many of those interviewed were still living in close proximity to the plantations where they had been enslaved. This 
created ties to the land and ties to the community-both black and white. Given this context, informants were less likely to feel free to disclose negative experiences, given that the descendants of their former masters lived nearby. Further, the interviewers were from the same area. Therefore it was certainly plausible, from the perspective of the informant, that any information expressed by the informant might be conveyed to those descendants. Indeed some of the interviewers were descendants of the slaveholders who owned their interviewees (Rawick, 1977a, lxxxviii). It is timely that few narratives were compiled in publication prior to the 1970s, by this time most of the former slaves had died and were not subject to retribution on the part of the descendants of slaveholders.

Marjorie Woods Austin, a writer from the Mississippi Writer's Project who was interviewed about her former interviewing experiences (albeit forty years later), was from an upper class white family. When asked how she located former slaves, she commented:

Well, I talked a lot about my project, and being a native, I knew everybody... I knew about these people, these Negroes; one I knew personally... the thing to do was to locate them... tell him that a lady wanted to come to see him to get him to tell her the way things were when he was young (Rawick, 1977a, lxxxiii).

In this statement, Austin is establishing the partial identities of the interviewer and interviewee. She was a self-defined lady and her interviewees were "these people, these Negroes." Her choice of the term "these" instead of "those" indicated a proximal intimacy that is not reflected in her account of the interviews. She also established status. If a white "lady" sought an interview in Jim Crow era Mississippi, a black man or woman would be expected to provide it.

Mrs. Austin recalled an interview with Nettie Henry: "So she'd been to the parties and all the family affairs that I knew about, and she mentions members of my family" (ibid.). This was what was of interest to her about this particular narrative. She recounted how she kept a copy of that interview and sent it around the country to family members from the North who delighted in reading it to dinner guests for entertainment. Clearly in this case the interviewer had an impact on the narratives that were created in the context of the interview. There is very little known about the other writers who worked for the Mississippi Writer's Project, except that they were white women who likely had some direct or indirect potential influence upon the lives of those they interviewed. This influence mediated the interviews. Mark Twain related a lesson he learned from a sermon of a former slave:

"You tell me where a man gets his corn pone, and I'll tell you what his 'pinions is." I can never forget it... The black philosopher's idea was that a man is not independent, and cannot afford views which might interfere with his bread and butter. If he would prosper, he must train with the majority; in matters of large moment, like politics and religion, he must think and feel with the bulk of his neighbors, or suffer damage in his social standing and in his business prosperities. He must restrict himself to corn-pone opinions-at least on the surface (quoted in Rawick, 1977a, lxxxviii).

Most of the Mississippi slave narratives reflect this philosophy. Several former slaves from this region reported that they were better off as slaves. This response was likely as much a consequence of the constraints placed on their ability or willingness to speak openly as the lack of qualitative change in their daily lives after emancipation. For some, the challenges of daily life got worse after slavery, particularly during the 
Depression, when the interviews were elicited. Photographs that accompany some interviews reflect the destitution of a number of the interviewees. Typically an elderly African American is pictured on the porch or steps of a dilapidated wooden cabin wearing worn-out clothing that reflects limited economic means. Regardless, many acknowledged the significant difference between slavery and freedom. Jack Aldredge stated: "No sir, young people dis day and time sho has a heap better time than we did back in dem slavery times" (Rawick, 1977a, 22).

Another interesting aspect of the Mississippi narratives is that some were written in third person. Thus the interviewer becomes the narrator. This method assimilates the paternalism of slavery, the interviewer tells the story for the interviewee. Consequently, the interviewer appropriates the voice of the informant. Following is an excerpt from such a narrative:

She often says "I had a much easier time when I was a slave" [...]. As the Johnson family grew, Matilda states that she was treated just as good as the children. The only difference being that she was black and they were white. She is a firm believer in the traditions of slavery [...]. She praises the slave days and likes to tell how good her Master and Mistress were to her (Rawick, 1977b, 412-13).

This narrative came from an interview with Matilda Clifton, a former slave who was 113 years old at the time of the interview. She was living alone and continued to work at this advanced age. The problems that accompany the aging process probably influenced this, and other, narrative(s). Looking back at the past entails a comparison with the present. The problems of the past may seem minimal in comparison. That Mrs. Clifton perceived that she had a much easier time when she was a slave may be independent of her slave status and may have more to do with her age, her health, and her social network during that timeframe in comparison to her present condition.

The interview with Frances Cobb was prefaced by this statement: "This interview was very disappointing, as the old negro seemed less intelligent than others I've talked with. She lives with her only daughter in a comfortable cabin, which is unusually clean. The Cabin is owned by white people, for whom they wash and iron" (Rawick, 1977b, 416). These comments indicate that Cobb was still directly dependent on whites for her livelihood. According to Twain's prediction (which he learned from a former slave), one can suspect that her comments reflect this. This turns out to be the case and some of her comments will be discussed as an example of the "corn pone narratives" that are heavily mediated by the social, regional, and temporal as well as personal context.

Yes'm Mars George Harris was good to us, He would come to the quarter every week and bring us chillern candy and cake... No'm, not on dat plantation was any slave punished. I heard it said, dat some was... I never heard of no trouble between whites and blacks 'cept the patrollers... I ain't been to no cornshucking but I seen dem down on de place on moon shining nights. De would holler and sing... When de surrender come in May we just stayed the year out til Christmas. Then we moved into Lowndes County... Old as I is, who is taking care of me? De good Lord! Now he told you to come and give me dis money dis morning and I was't thinking about it (ibid., 422).

The interviewer's judgment of Cobb's intelligence is likely related to the fact that she made her responses to questions brief, did not narrate very extensively, was careful to use 'ma'am,' and cast her comments about her experiences in a positive light. This indicates the circumscribed nature of her responses. Brevity is a strategy of selfprotection. 

incentive. The interviewer gave her money, so she did not want to offend her. The statements she made about her experiences during slavery were innocuous. She used the distancing strategy of having heard about or seen, from a distance, negative things or events. She used "they" instead of "we" in her narrative. She discussed emancipation as essentially a non-event. It eventually led to a move and a shift to share-cropping, but the event is not narrated in detail as it is in a number of slave narratives from other regions. Emancipation was a critical event, the end of a chapter, and Cobbs discussed it incidentally.

What is "not said" about emancipation brings to mind Foucault: "this 'not-said' is a hollow that undermines from within all that is said" $(1993,25)$. The "not said" is a consequence of the "repressive manifest discourse" and its absence, in the face of known presence, undermines the validity of what is expressed. Silence is a key strategy. Geographic context plays a critical role. For many former slaves in Mississippi, emancipation was somewhat of a non-event, in the strict sense that it did not lead to a qualitatively different way of life. Many former slaves in Mississippi continued to work for their former owners or worked on another, similar plantation. 'Free' is a relative term. The contingent nature of freedom is adequately appreciated by considering the comments of Ezra Adams, another former slave from Mississippi:

You ain't gwine to believe dat de slaves on our plantation didn't stop working for old master, even when they was told dat they was free. Us didn't want no more freedom than us was gittin' on our plantation already. Us knowed too well dat us was well took care of, wid a plenty of viddles to eat and tight log and board houses to live in. De slaves where I lived, knowed after de war dat they had abundance of dat somethin' called freedom, what they could not eat, wear, and sleep in... Dis livin' on liberty is lak young folks livin' on love after they gits married. It just don't work. No, sir, it las' so long and not a bit longer... It sho' don't hold good when you has to work, or when you gits hongry (Smith, 1997, 28).

ntil the civil rights movement in the 1960s there were some African Americans in some areas of Mississippi who were never paid money for their labor. They worked for whites who would give them room and board and supply bare necessities as an exchange. Freedom is circumscribed by context and social structure. Freedom without opportunity or equality was an alternative form of racially defined bondage. Adams' position on slavery changed after he acquired his own land. He stated: "If a poor man wants to enjoy a little freedom let him go on de farm and work for hisself. It is sho' worth something to be boss, and, on de farm you can be boss all you want" (ibid.). Freedom, then, is related to the ability to work for oneself and not work for someone else. It is also related to being in control. These conceptions reflect visions of freedom that are associated with the system of slavery. Freedom could be defined in relation to any number of variables, but control over labor and the position of boss are those that Adams chose.

63 A tangible distinction exists in the tone and content of narratives of former slaves who left the community in Mississippi they lived in under slavery. George Washington Albright is an example of such an individual. His story was recorded in New York by a newspaper interviewer, but the interview was included in the Mississippi W.P.A. Narratives because a copy was found in the Mississippi archive. Rather than depicting slavery in a positive light, couching negative statements in terms that indicate that the former slave was responsible for initiating harsh treatment (Rawick, 1977b, 502, 690), 
or giving vague and brief descriptions of negative events, Albright narrates in relative detail about murders of blacks by whites and other social and political problems faced by African Americans from slavery into the contemporary present (Rawick, 1977a, 10-19). The variance of discourse between those still rooted in the same geographical context and those who have moved away from it is related to the relative ability to be able to "extricate or distance oneself from embeddedness in the action and perceive it in the manner of a plot, a history. We often do this when a certain episode of one's life has reached a (perhaps temporary) conclusion" (Kerby, 1991, 37). Physical distance creates social distance and allows one to differentiate more clearly between past and present. In the absence of physical distance, there is the consequent lack of social distance and the division between past and present becomes less easy to discern. White opposition impacted the ability of some freedpersons to become free in reality as well as free in principle. To paraphrase George King, freedpersons were all free, but it didn't mean they were white and it didn't mean they were equal.

\section{Conclusion}

Slave narratives provide a means of accessing the multifaceted identities of former slaves, their sense of themselves, and how it was constructed within the society in which they lived. Discourse analysis reveals that these identities were fabricated from strands of social, geographical, personal, cultural, and temporal context. These contexts were mediated by the legacy of slavery and constructions of race and ethnicity. These constructions impacted identity. Self-identity and imposed identity were woven into a sense of self and these are expressed and sanctioned through narrative. Audio narratives offer insight into linguistic strategies that are inaccessible in the written narratives. Pauses, silences, change in tone and pitch, and word emphasis confer a three-dimensional aspect to the narratives and saturate them with new meanings. An analysis of spoken and written narratives about slavery reveals that the fluid boundaries of identity have real historical, ethnic, temporal, and cultural restraints. The power of words is illustrated by the attempts, successful and otherwise, to modify narratives and to obscure, destroy, and invalidate them. These strategies, on the part of some interviewers and project employees, reveal that these individuals realized that the narratives revealed aspects of their identity and heritage as well as those of the African American interviewees. Within and through the construction of the narratives, power and identity were negotiated on a number of levels.

The analysis of audio and written narratives shows that these narratives embody a negotiated identity, one that has been mediated by the context of the interview and subsequent modification to the documents in the form of editing by the interviewers and their supervisors. In the articulation of the interviewer's definition of the slave experience (which is shaped by their questions and through editing), and the informant's self-definition, a third slave identity emerges that is a reconstitution and negotiation of these divergent and conflicting perspectives. This identity is reconstituted and negotiated through the historical, geographic, cultural, and ideological context in which it is situated. The narratives become, rather than the expected voice or vehicle for expression of the former slaves' experiences in their own words, multi-authored texts that reflect white Southerner's beliefs about slavery as well as the former slaves' lived experiences. 
One of slavery's deepest brutalities was the attempted reduction of people to things. Through narrative, former slaves resisted objectification and transformed themselves into subjects. As subjects, they were able to relate their experiences and understandings of slavery and freedom. Whatever the implications of freedom, once emancipation occurred those who had been slaves were no longer slaves and to forget that, as Sidney Mintz warns, is "to forget too much" $(1992,255)$. Identity is brought to the fore at times of swift change and social dislocation. The era of emancipation and reconstruction in the United States impacted the creation of a new identity, the freed person. The identity of freed individuals was not constructed in a vacuum. Rather it was developed in the context of the legacy of slavery and in relation to former identity. This era was a liminal period with the potential of moving toward healing racial inequality. Unfortunately, events took the opposite direction and racial inequality was reified and codified in various state and federal laws.

The concept of race in America was reified on the slave plantation (Durant Jr., 1999, 11). A racially defined slave status fostered the development of racial and economic inequality. This racial system established a legacy that continued long after the collapse of the physical plantation system of slavery. These events impacted the negotiation of the identities of all members of the nominally integrated society. The negotiation of identity through the macrodiscourse of slavery weaves together black and white strands of perspective. When black and white are interwoven, they create gray. Through polishing, with the words of interviewers and interviewees, gray becomes silver. This silver tapestry, the collection of slave narratives, has a reflective quality and by looking carefully at this tapestry the multifaceted identities of former slaves are revealed to the reader. Like a mirror, the tapestry has imperfections and aspects of identity are distorted in places. The reflection is one of a fragmented, negotiated identity that represents the convergence of varying perspectives on the experiences of slavery and their impact on identity. However, neither the interviewees nor the interviewers would recognize the reflections cast by the tapestry as a true reflection of their conceptions of self-identities or imposed identities. It represents rather a reconstruction of deconstructed and (re)contextualized aspects of both.

\section{BIBLIOGRAPHIE}

ALLEN, William, Lucy GARRISON, and Charles WARE, Slave Songs of the United States, Massachusetts, Applewood Books, 1867.

BAKER, T. Lindsay and Julie, eds., The W.P.A. Oklahoma Slave Narratives, Norman (OK), University of Oklahoma Press, 1996.

BAKHTIN, Mikhail "Discourse in the Novel," in Michael Holquist, ed., translated into English by Caryl Emerson and Michael Holquist, The Dialogic Imagination, Austin, University of Texas Press, 1981, 259-422. 
BAR-ON, Dan and Noga GILAD, “To Rebuild Life: A Narrative Analysis of Three Generations of an Israeli Holocaust Survivor's Family," in Amia Lieblich and Ruthellen Josselin, eds., Exploring Identity and Gender: The Narrative Study of Lives, Thousand Oaks, CA, Sage, 1994, 82-112.

BERLIN, Ira, Marc FAVREAU and Steven MILLER, eds., Remembering Slavery, New York, New Press, 1998.

BLASSINGAME, John, ed., Slave Testimony, Baton Rouge, Louisiana State University Press, 1977.

BOURHIS, R.Y. and Howard GILES, “The Language of Intergroup Distinctiveness," in Howard Giles, ed., Language, Ethnicity, and Intergroup Relations, London, Academic Press, 1977, 119-35.

BRIGGS, Charles and Richard BAUMAN, “Genre, Intertextuality, and Social Power," in Ben Blount, ed., Language, Culture, and Society, Prospect Heights (IL), Waveland Press, Inc., 1995, 567-603.

COMAROFF, John and Jean, Ethnography and the Historical Imagination, San Francisco, Westview Press, 1992.

CONLEY, John and William O'BARR, Just Words, Chicago, University of Chicago Press, 1998.

COULTHARD, Malcolm, The Introduction to Discourse Analysis, second edition, New York, Longman, 1985.

CURTIN, Philip, "The Black Experience of Colonialism and Imperialism," in Sidney Mintz, ed., Slavery, Colonialism, and Racism, New York, W.W. Norton and Company, 1974.

DOBRIN, Sidney, "Race and the Public Intellectual: A Conversation with Michael Eric Dyson," in Gary Olson and Lynn Worsham, eds., Race, Rhetoric, and the Postcolonial, Albany, State University of New York Press, 1999.

DURANT, Jr. Thomas, "The Slave Plantation Revisited," in Plantation Society and Race Relations: The Origins of Inequality, Thomas Durant Jr. and David Knottnerus, eds., Westport (CT), Praeger, 1999.

DURANT, Jr. Thomas and J. David KNOTTNERUS, eds., Plantation Society and Race Relations: The Origins of Inequality, Westport (CT), Praeger, 1999.

FISCHER, Michael, "Ethnicity and the Post-Modern Arts of Memory," in James Clifford and George Marcus, eds., Writing Culture, Berkeley, University of California Press, 1986.

FOUCAULT, Michel, The Archaeology of Knowledge, translated into English by A.M. Sheridan Smith, New York, Barnes and Noble Books, 1993.

FREDERICKSON, George, The Black Image in the White Mind, Middletown (CT), Wesleyan University Press, 1971.

---, The Arrogance of Race, Middleton (CT), Wesleyan University Press, 1988.

GATES, Jr., Henry, ed., The Classic Slave Narratives, New York, Penguin Books, 1987.

GILES, H. and P. JOHNSON, "The Role of Language in Ethnic Group Relations," in J. Turner \& H. Giles, eds., Intergroup Behavior, Chicago, University of Chicago Press, 1981, 199-243.

GOMEZ, Michael, Exchanging Our Country Marks, Chapel Hill, The University of North Carolina Press, 1998.

GUDYKUNST, William, ed., Language and Ethnic Identity, Philadelphia, Multilingual Matters Ltd., 1988.

GUMPERZ, John, Discourse Strategies, London, Cambridge University Press, 1982a.

---, Language and Social Identity, London, Cambridge University Press, $1982 \mathrm{~b}$. 
HARTMAN, Saidiya, Scenes of Subjection, New York, Oxford University Press, 1997.

HENSEL, Chase, Telling Our Selves: Ethnicity and Discourse in Southwestern Alaska, New York, Oxford University Press, 1996.

HYMES, Dell, "Models of the Interaction of Language and Social Life," in John Gumperz and Dell Hymes, eds., Directions in Sociolinguistics, New York, Holt, Rinehart, and Winston, 1972.

JESSEL, Levic, The Ethnic Process, Contributions to the Sociology of Language, New York, Mouton Publisher, 1978.

JOHNSON, Walter, Soul by Soul: Life Inside the Antebellum Slave Market, Cambridge, Harvard University Press, 1999.

KERBY, Anthony, Narrative and the Self, Bloomington, Indiana University Press, 1991.

LOUW-POTGIETER, Joha and Howard GILES, "Imposed Identity and Linguistic Strategies," in William Gudykunst, ed., Language and Ethnic Identity, Clevedon, UK, Multilingual Matters Ltd., 1988.

MARIN, G., H.C. TRIANDIS, H. BETANCOURT, and Y. KASHIMA, "Ethnic Affirmation versus Social Desirability," Journal of Cross-Cultural Psychology, 14, 1983, 173-86.

MCGLYNN, Frank and Seymour DRESCHER, eds., The Meaning of Freedom, Pittsburgh, University of Pittsburgh Press, 1992.

MINTZ, Sidney, "Panglosses and Pollyannas; or, Whose Reality are we Talking About?" in S. McGlynn and F. Drescher, eds., The Meaning of Freedom, Pittsburg, University of Pittsburgh Press, 1992.

NIEMAN, Donald, ed., The Freedman's Bureau and Black Freedom, New York, Garland Publishing, Inc., 1994.

NORWOOD, Hermond, Interview of Fountain Hughes, July 11, 1949, http://xroads.virginia.edu/ rhyper/wap/hughes1.html (last accessed on December 1, 1999).

OCHS, Elinor and Lisa CAPPS, "Narrating the Self," Annual Review of Anthropology, 25, 1996, 19-43.

OLSON, Gary and Lynn WORSHAM, eds., Race, Rhetoric, and the Postcolonial, Albany, State University of New York Press, 1999.

OWEN, Robert, The Wrong of Slavery, The Right of Emancipation, Philadelphia, J.B. Lippincott, 1864.

RAWICK, George, ed., The American Slave: A Composite Autobiography, Supplement, series 1, vol. 6, Mississippi Narratives: Part 1, Jan Hillegas and Ken Lawrence, eds., Westport, CT, Greenwood Press, 1977a.

---, ed., The American Slave: A Composite Autobiography, Supplement, series 1., vol. 7. Mississippi Narratives: Part 2, Jan Hillegas and Ken Lawrence, eds., Westport, CT, Greenwood Press, $1977 \mathrm{~b}$. SCHILLINGSBURG, Peter, Resisting Texts, Ann Arbor, University of Michigan Press, 1997.

SMITH, John, Black Voices from Reconstruction 1865-1877, Gainesville, University Press of Florida, 1997. 


\section{NOTES}

1. In the following excerpts from the narratives of former slaves, italicized words indicate words that were emphasized. Ellipses indicate that parts of the narrative were left out. Pauses are indicated by dashes.

2. Fountain Hughes was born into slavery in 1848 in Charlottesville, Virginia. His grandfather, Wormley Hughes, was owned by Thomas Jefferson. Fountain Hughes moved to Washington D.C. and then to Baltimore, Maryland where he worked as a gardener until he was ninety-eight years old. He lived in Baltimore until his death in ca. 1952.

3. Mrs. Laura Smalley was born into slavery on a plantation near Hempstead, Texas. Her mother was from Mississippi.

4. Harriet Smith was born into slavery in 1851 in Hempstead, Texas. Her former owner was Jim Bunton.

\section{RÉSUMÉS}

Les récits se construisent dans des contextes spécifiques, notamment temporels, culturels, géographiques, historiques, idéologiques, et physiques. La création en contexte de récits d'esclaves et leurs processus de construction et de reconstruction aboutit à une négociation des rapports de pouvoir qui pèsent sur l'authenticité du discours de l'esclave. Dans cet essai, des récits d'anciens esclaves américains enregistrés dans les années 30 et 40 sont examinés pour explorer la façon dont le contexte et le récit négocient l'identité et le pouvoir dans ces contextes. Une attention particulière est portée à la façon dont les individus parlent de l'esclavage et dont leurs mots sont révélateurs de relations d'identité et de pouvoir. Ces récits sont complétés par des récits et documents supplémentaires écrits par des Anglo-Américains pour souligner davantage encore les différences de perspective sur l'esclavage, la liberté, et l'identité.

The construction of narratives takes place within specific contexts, including temporal, cultural, geographical, historical, ideological, and physical. The contextual creation of slave narratives and the processes of their construction and reconstruction resulted in a negotiation of power over the authentic discourse of slavery. In this essay, narratives of former U.S. slaves recorded in the 1930s and 1940s are examined to explore how context and narrative negotiate identity and power within these contexts. Particular attention is focused on how individuals talk about slavery and how their words are indicative of identity and power relations. These narratives are supplemented with additional narratives and documents written by Anglo-Americans to further highlight different perspectives of slavery, freedom, and identity.

\section{INDEX}

Keywords : Slavery, slave narratives, discourse, identity, race, context, power, discourse analysis, Works Progress Administration

Mots-clés : Esclavage, récits d'esclave, discours, identité, race, contexte, pouvoir, analyse de discours, Works Progress Administration 
AUTEUR

LORI LEE

Randolph College 